\title{
Giant Anterior Staphyloma After Bomb Explosion
}

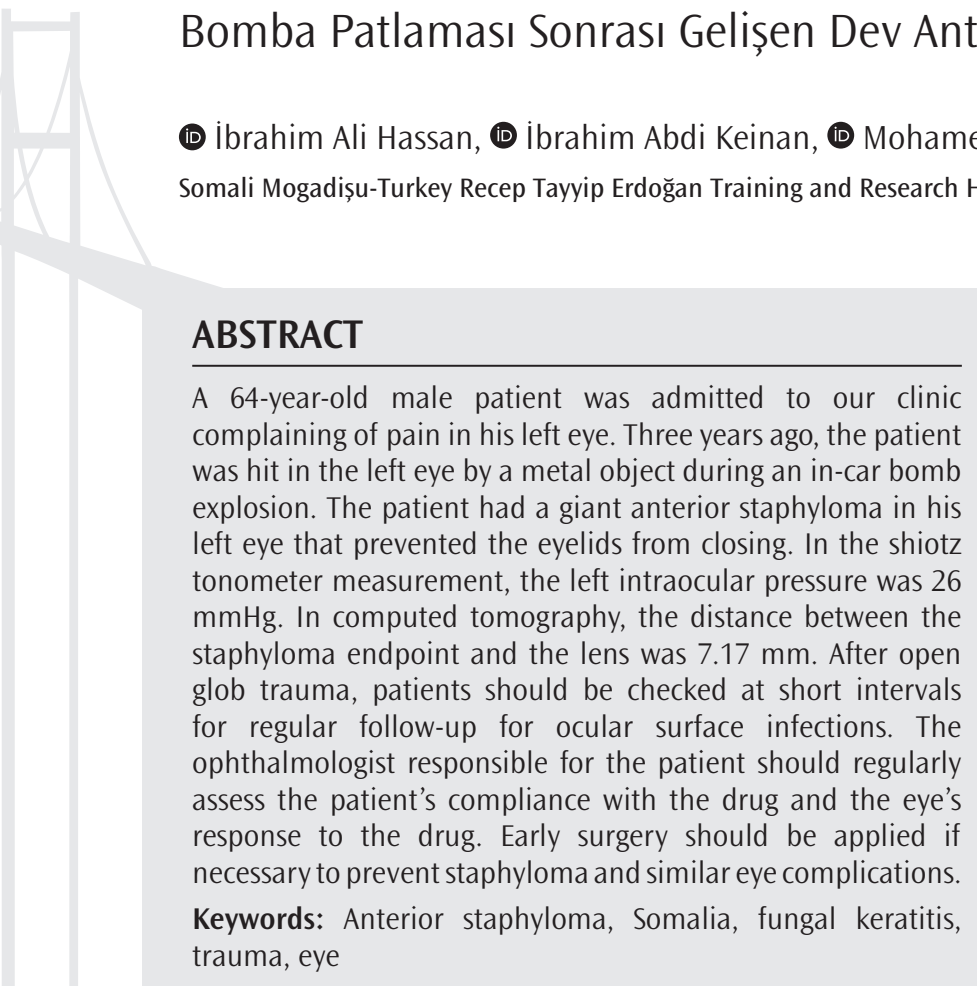

\section{öZ}

Altmış dört yaşında erkek hasta sol gözünde ağrı şikayeti ile kliniğimize başvurdu. Hastanın 3 yıl önce sol gözüne araç içi bomba patlaması sırasında metal bir cisim çarpmıştı. Hastanın sol gözünde kapakların kapanmasını engelleyen dev anterior stafilom vardı. Shiotz tonometre ölçümünde sol göz içi basıncı $26 \mathrm{mmHg}$ idi. Bilgisayarlı tomografide stafiloma uç noktası ile lens arasındaki mesafe 7,17 mm idi. Açık glob travmasından sonra hastalar, oküler yüzey enfeksiyonları açısından düzenli takip için kısa aralıklarla kontrol edilmelidir. Hastadan sorumlu göz doktoru, hastanın ilaca uyumunu ve gözün ilaca verdiği yanıtı düzenli olarak değerlendirmelidir. Stafilom ve buna benzer göz komplikasyonlarının olușmasını önlemek için gerekirse erken cerrahiye başvurulmalıdır.

Anahtar Kelimeler: Ön stafilom, Somali, fungal keratit, travma, göz

\section{Introduction}

Anterior staphyloma means that in corneal tears, the iris comes forward and covers the defect and then integrates with the corneal scarification. There are 4 types of staphyloma. These are anterior, intercalary, equatorial, and posterior staphylomas. Perforant injuries, peripheral corneal ulcers, absolute glaucomas, sclerites and pathological myopies can cause weakening of the outer sphere of the eye and ultimately staphyloma (1,2).

Anterior staphylomas located in front of the equator are called calare type if they are above the ciliary body; intercalare type if they are between the ciliary body and the limbus (3). It is probably due to a combination of infection and high intraocular pressure (3). Patients' complaint of admission is an opaque, enlarged and protruded eye that usually accompanies vision loss. In differential diagnosis, malignant melanoma, buphthalmus, axial myopia and coloboma should be considered. Penetrating keratoplasty and enucleation have a place in treatment.

\section{Case Report}

A 64-year-old male patient was admitted to our clinic complaining of pain in his left eye. His left eye was normal. Written consent was obtained from the patient. A detailed history of the patient found out that he had a history of trauma to the left eye 3 years ago. A metal object ricocheting off a car bomb detonated in Somalia hit his left eye. He later described being admitted to a local clinic in the area where he was found and the metal object was removed from his eye and his eye was covered with tight bandages. Afterwards, he was diagnosed with post-traumatic fungal keratitis at another eye clinic he had been admitted to, but he had not responded to treatment. After a long time, the patient was brought to our clinic by his relatives.

In a detailed eye examination, the best adjusted visual acuity was $10 / 10$ in the right eye and the level of light sensation in the left eye. On a biomicroscopic examination, the right cornea was transparent, the crystallized lens was natural, and the anterior chamber was shaped. The patient had a giant anterior staphyloma in his left eye that prevented 
the eyelids from closing (Figure 1, 2). Crystallized lens and fundus in the same eye could not be evaluated. The intraocular pressure in the right eye was $19 \mathrm{mmHg}$ with the Goldmann aplanation tonometer. In the schiotz tonometer measurement, the left intraocular pressure was $26 \mathrm{mmHg}$.

The patient had no history of systemic disease. Computed tomography showed no foreign body and the lens was in normal position, the distance between the lesion endpoint and the lens was $7.17 \mathrm{~mm}$ (Figure 3).

The patient was diagnosed with total anterior staphyloma, a rare pathology of the anterior segment that occurs as a result of protrused uveal tissue from the damaged area of the cornea or sclera as a result of trauma or corneal ulcer. Sclero-keratoplasty was recommended for treatment. Because the patient did not accept surgery, he was given brimonidine and dorzolamide + timolol eye drop treatment due to the height of intraocular pressure.

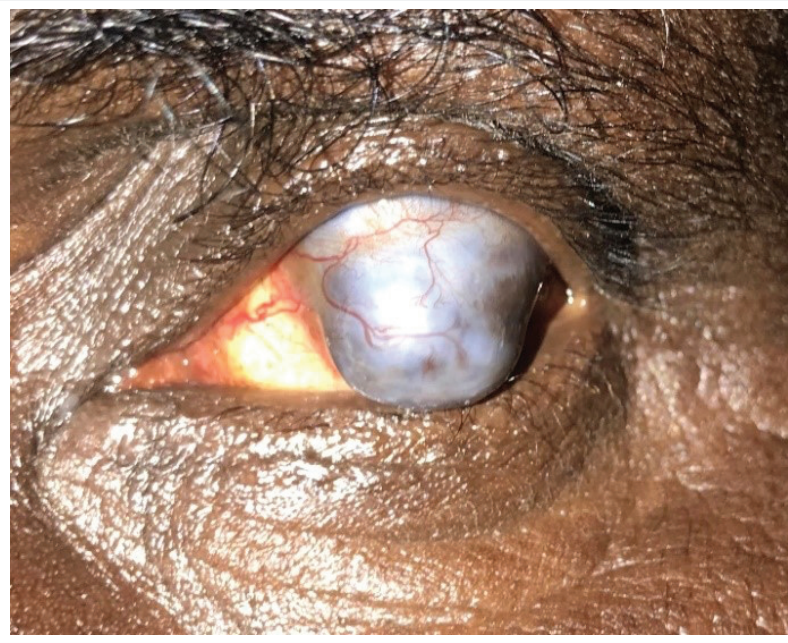

Figure 1. Anterior staphyloma, vascularized, white in color

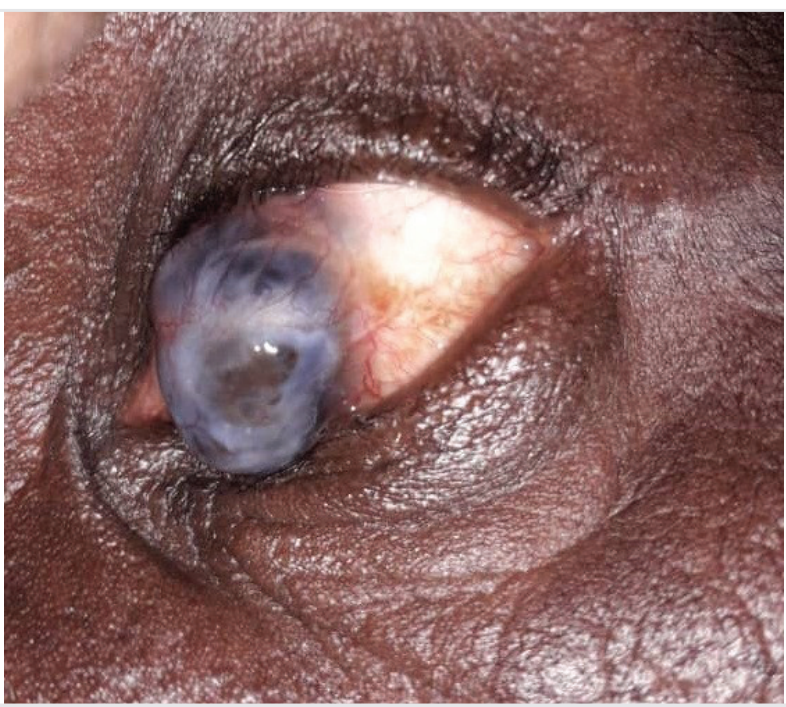

Figure 2. Lateral appearance of anterior staphyloma in vascularized, white color

\section{Discussion}

Anterior staphyloma typically occurs in low-income countries due to lack of post-traumatic care followed by infectious keratitis (4). In this patient, a noticeable piece of metal after the bomb explosion punctured the ocular sphere and caused the uveal tissue to protrude from the cornea.

Similar to our case, anterior staphyloma occurs when corneal perforations are not treated or there is no response to treatment initiated due to penetrating injury. When the cornea becomes lasere, the iris clogs the incision site and forms a pseudocornea above the wound. Simultaneous increased intraocular pressure increases the protrusion of the iris (5).

Ocular trauma cannot be avoided, but its consequences can be avoided. From this point of view, first diagnosis and then treatment are very important. Anterior staphyloma treatment is usually based on removing the tissues that make up the staphyloma from the eyeball and restoring the eyeball using the sclero-keratoplasty technique (6). Currently, total anterior staphylomas are quite rare due to the ease of access to treatment.

Neovascular glaucoma, endophthalmia and uveal-choroidal melanoma are important in the differential diagnosis of anterior staphyloma. The fact that our patient complained of pain suggested that there may be a case of anterior staphyloma accompanied by neovascular glaucoma.

Uvea melanoma is the most common primary malignant intraocular neoplasm in adults, and the 10-year mortality after diagnosis and treatment is around $30-50 \%(7,8)$. The separation of anterior staphyloma from uveal malignant melanoma is very important both in terms of treatment and follow-up. The absence of pain in staphyloma is a clinically important finding in moving away from the diagnosis of malignant melanoma. But our patient complained of pain in the eye, suggesting the possibility of malignant melanoma. After antiglaucomatous treatment, which we started due to high intraocular pressure, the eye pain had passed. This case has shown that we should be alert to the possibility of malignant melanoma in cases that look like a anterior staphyloma in appearance, but appear as a painful eye.

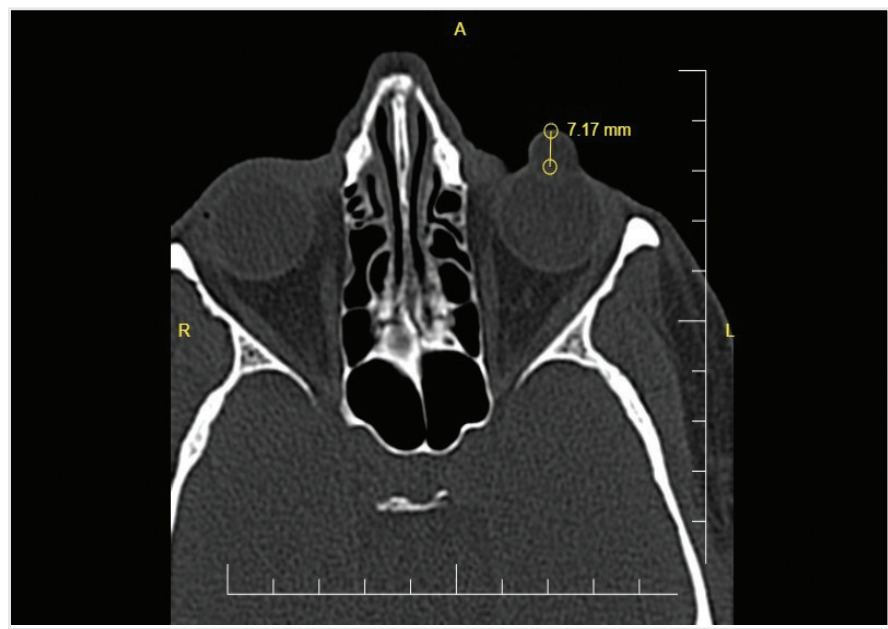

Figure 3. In computed tomography, the distance between the lesion endpoint and the lens is $7.17 \mathrm{~mm}$ 


\section{Conclusion}

After open glob trauma, patients should be checked at short intervals for regular follow-up for ocular surface infections. The patient's ophthalmologist should regularly assess the patient's compliance with the drug and the eye's response to the drug. Early surgery should be sought if necessary to prevent the occurrence of eye complications such as anterior staphyloma. Uveal malignant melanoma should be kept in mind in painful eyes with total anterior staphyloma.

\section{Ethics}

Informed Consent: Written consent was obtained from the patient.

Peer-review: Externally peer-reviewed.

Authorship Contributions: Surgical and Medical Practices - I.A.H., I.A.K.; Concept - I.A.K., M.K.; Design - I.A.K., M.S.K.; Data Collection or Processing - I.A.H.; Analysis or Interpretation - I.A.H., I.A.K., M.S.K., M.K.; Literature Search - I.A.H.; Writing - I.A.H., I.A.K., M.K.

Conflict of Interest: No conflict of interest was declared by the authors.

Financial Disclosure: The authors declared that this study received no financial support.

\section{References}

1. Joseph A, Prakash J, Shastri D. Anatomical distortion in a rare case of staphyloma: A case report. NJBMS 2016; 6: 120-2.

2. Khurana A, Khurana B. Comprehensive Ophthalmology: With Supplementary Book-Review of Ophthalmology; 2015.

3. Eva PR, Augsburger J. Vaughan \& Asbury's general ophthalmology. 19th ed. 2007.

4. Singh RB, Thakur S, Singh KP. Blueberry eye: acquired total anterior staphyloma. BMJ Case Rep 2018; 2018: bcr2018224271.

5. Grieser EJ, Tuli SS, Chabi A, Schultz S, Downer D. Blueberry Eye: Acquired Total Anterior Staphyloma After a Fungal Corneal Ulcer. Cornea 2009; 28: 231-2.

6. Cobo M, Ortiz JR, Safran SG. Sclerokeratoplasty with Maintenance of the Angle. Am J Ophthalmol 1992; 113: 533-7.

7. Egan KM, Seddon JM, Glynn RJ, Gragoudas ES, Albert DM. Epidemiologic aspects of uveal melanoma. Surv Ophthalmol 1988; 32: 239-51.

8. Khetan V, Gupta K, Mohan ER, Gopal L. Uveal melanoma presenting as cataract and staphyloma. Indian J Ophthalmol 2009; 57: 223-5. 